\title{
Antiproliferative activity of selected medicinal plants of Jordan against a breast adenocarcinoma cell line (MCF7)
}

\author{
Rana Abu-Dahab ${ }^{1^{*}}$ and Fatma Afifi ${ }^{2}$ \\ 1. Dept. of Biopharmaceutics and Clinical Pharmacy, Faculty of Pharmacy, \\ University of Jordan, Amman11942, Jordan \\ 2. Dept. of Pharmaceutical Sciences, Faculty of Pharmacy, University of Jordan, \\ Amman, Jordan
}

\begin{abstract}
76 ethanolic extracts of medicinal herbs from the Jordanian flora, belonging to 67 species and 34 families, were evaluated for their antiproliferative activity on a breast cancer cell line (MCF7). The cells were cultured in RPMI 1640 medium and incubated with the extracts for 72 hours. Sulphorhodamine B (SRB) assay was used to test cytotoxicity.

From the tested crude extracts, Inula graveolens, Salvia dominica, Conyza canadiensis and Achillea santolina showed potent antiproliferative activity and the activity resided in the chloroform/ethanolic extracts. The most active plant was $I$. graveolens with an $\mathrm{IC}_{50}$ of $3.83 \mu \mathrm{g} / \mathrm{ml}$. Phytochemical screening indicated the presence of flavonoids, terpenoids, and phenolics in all active extracts. These results indicate the possible potential use of medicinal plants from the Jordanian flora as antineoplastic agents.
\end{abstract}

\section{Key words}

Antiproliferative activity, SRB, Medicinal plants, Jordan, MCF7 


\section{Introduction}

Since medieval times, plants have been the source of medicines for the treatment of diseases. Regardless of the availability of a wealth of synthetic drugs, plants remain - even in the $21^{\text {st }}$ century - an integral part of the health care in different countries, especially the developing ones. In the late 90's, the WHO stated that a big percentage of the world's population depends on plant based therapies to cover the needs of the primary health care (WHO 1999) [1]. Moreover, towards the end of the $20^{\text {th }}$ century, plant based OTC products, nutroceuticals and food supplements comprising the complementary and alternative therapies have gained a big share in the drug market in the developed countries.

Medicinal plants -either through systematic screening programs or by serendipity - possess an important position in the drug discovery and many modern drugs have their origin in traditional medicine of different cultures. Hence, despite the advantages of the synthetic and combinatorial chemistry as well as molecular modeling, medicinal plants remain an important source of new drugs, new drug leads and new chemical entities [2, 3]. The latter study reported that of the 877 small molecule new chemical entities (NCEs) introduced between 1981 and 2002 nearly the half (49\%) were natural products, semi-synthetic natural products, semi-synthetic natural products analogues or synthetic compounds based on natural products.

The areas of cancer and infectious diseases have a leading position in utilization of medicinal plants as a source of drug discovery. Among FDA approved anticancer and anti-infectious preparations drugs of natural origin have a share of $60 \%$ and $75 \%$ respectively [3]. It is worthy to mention the vivid current interest in discovery of natural drugs for cancer treatment and chemoprevention [4, 5]. Huge number of plant species is screened and bioassayed for this purpose worldwide [6-17].

In many countries, cancer is the second leading cause of death after heart diseases $[15,18]$. The estimated worldwide incidence of different carcinomas is about 
10 million; half of these are in developed countries [13]. Among the cancer patients in the USA, the use of complementary and alternative medicine, represented mainly by plants, ranges between $30-75 \%$ [6]. This in turn justifies the interest in search of possible anticancer agents from the flora of different countries.

In accordance with this worldwide trend, the current study was undertaken to screen the ethanolic extracts of 67 plant species found in the Jordanian flora or sold by the local herbalist shops. Among the screened plants there are only few plants recommended by the traditional healers for the treatment of cancer (i.e Arum palestinum) while some tested plants are belonging to the genera with reported anticancer activities (i.e. Salvia dominica).

\section{Experimental}

\section{Plant extracts' preparation}

Plant samples collected during spring/summer 2005 or purchased in the same period were dried at room temperature and finely ground with a hammer mill. Each 2.5 g powdered plant material was extracted by refluxing with $25 \mathrm{ml}$ ethanol for $30 \mathrm{~min}$ and kept overnight at room temperature before filtration. After filtration, ethanol was evaporated until dryness and the crude extracts were weighed. $0.1 \mathrm{~g}$ of the crude extract was dissolved in dimethyl sulphoxide (DMSO) to a final stock concentration of $10 \mathrm{mg} / \mathrm{ml}$. All extracts were kept at $-20^{\circ} \mathrm{C}$ until cytotoxicity tests were carried out.

\section{Phytochemical screening}

Phytochemical screening using thin layer chromatography (TLC) was carried out only for plant species (Achillea santolina, Conyza canadiensis, Inula graveolens and Salvia dominica) indicating promising anticancer activity using MCF7 cell line. The ethanolic extracts were subjected to TLC examination for group determination of the 
secondary metabolites. Modified Dragendroff's reagent for alkaloids, ferric chloride reagent for phenolics, Naturstoff reagent for flavonoids, ethanolic $\mathrm{KOH}$ for coumarins and vanilline/sulfuric acid reagent for terpenoids were used. Solvent systems for the development of ready coated analytical TLC plates (Merck) were selected according to Wagner and Bladt [19].

\section{In vitro assay for cytotoxic activity}

\section{Cell culture}

The cell line under investigation was human breast adenocarcinoma (MCF7). It was purchased from the European Collection of Animal Cell Culture (ECACC No. 86012803). The cells were cultured in RPMI 1640 medium supplement with 10\% heated foetal bovine serum, $1 \%$ of $2 \mathrm{mM} \mathrm{l-glutamine,} 50 \mathrm{IU} / \mathrm{ml}$ penicillin and $50 \mu \mathrm{g} / \mathrm{ml}$ streptomycin.

According to the cells growth profile, cells were seeded with a density of 5000 cell/well. This number was sufficient to give a reliable reading with the SRB assay, which corresponded well with the cell number and was the one that gave exponential growth throughout the incubation period with the plant extracts.

\section{Cytotoxicity assay}

For the assay, cells were washed three times with phosphate buffer saline (PBS). PBS was decanted and cells detached with 0.025\% trypsin-EDTA (Sigma). RPMI 1640 was added to a volume of $10 \mathrm{ml}$. The cell suspension was centrifuged at $1000 \mathrm{Xg}$ for 10 minutes and the pellet was resuspended in $10 \mathrm{ml}$ of medium to make a single cell suspension. Viability of the cells was determined by trypan blue exclusion and it exceeded $90 \%$ as counted in a haemocytometer. The cell suspension was diluted afterwards to give the optimal seeding density and $100 \mu$ of the cell suspension was plated in a 96 well plate and incubated at $37^{\circ} \mathrm{C}$ in a humidified atmosphere containing $5 \%$ CO2. After 24 hours the cells were treated with the extracts or pure compounds. 
Each extract (initially dissolved in DMSO), was diluted with the medium and passed through a $0.2 \mu \mathrm{m}$ filter. $50 \mu \mathrm{g} / \mathrm{ml}$ of each extract was tested initially, and, from the results, the active extracts were considered to be those which gave less than $50 \%$ survival at exposure time 72 hours. The active extracts were further diluted in medium to produce eight concentrations $(0.1,0.5,1,5,10,25,50,100 \mu \mathrm{g} / \mathrm{ml})$ of each extract. $100 \mu \mathrm{l} /$ well of each concentration was added to the plates in six replicates. The final dilution used for treating the cells contained not more than $1 \%$ of the initial solvent, this concentration being used in the solvent control wells. The plates were incubated for 72 hours. At the end of the exposure time, cell growth was analyzed using the SRB assay. Two replicate plates were used to determine the cytotoxicity of each extract.

As positive control vincristine sulphate was used (Sigma, Lot No. 34H0447) at the concentrations of $0.05,0.1,0.5,1,5,10,25,50,100 \mathrm{nM}$. For the calculation of $\mathrm{IC}_{50}$ WinNonLin Professional Version 5.0.1 was used.

\section{Sulphorhodamine B assay}

After incubation for 72 hours, adherent cell cultures were fixed in situ by adding $50 \mu \mathrm{l}$ of cold $40 \%(\mathrm{w} / \mathrm{v})$ trichloroacetic acid (TCA) and incubated for $60 \mathrm{~min}$ at $4{ }^{\circ} \mathrm{C}$. The supernatant was then discarded and the plates were washed five times with demonized water and dried. $50 \mu \mathrm{l}$ of SRB solution ( $0.4 \% \mathrm{w} / \mathrm{v}$ in $1 \%$ acetic acid) was added to each well and incubated for $30 \mathrm{~min}$ at room temperature. Unbound SRB was removed by washing five times with $1 \%$ acetic acid. Then, the plates were air-dried and $100 \mu$ of $10 \mathrm{mM}$ Tris base $\mathrm{pH} 10.5$ (Sigma) were added to each well to solubilize the dye. The plates were shaken gently for 20 minutes on a plate shaker and the absorbance (OD) of each well was read on an ELISA reader at $570 \mathrm{~nm}$. Cell survival was measured as the percentage absorbance compared to that of the control (nontreated cells). 


\section{Results and Discussion}

In the present study, the cytotoxic effect of 76 ethanolic plant extracts that belong to 34 families on MCF7 cells were characterized by conducting cell viability assay stained with sulphorohdamine B. Cultures of MCF7 cells were treated with the extracts first at one concentration of $50 \mu \mathrm{g} / \mathrm{ml}$ and the results are shown in Table 1. Control assays were carried out for samples containing only the appropriate volumes of blank solutions and those showed no effect on cell growth.

For plant extracts that showed less than $50 \%$ survival rate, further dilutions were made to calculate the exact $\mathrm{IC}_{50}$ values (Figure 1 and Table 2). For the most potent extracts, their antiproliferative activity was studied again using chloforom and water extracts (Table 3).

In the US NCI plant screening program, a crude extract is generally considered to have in vitro cytotoxic activity if the $\mathrm{IC}_{50}$ value (concentration that causes a $50 \%$ cell kill) in carcinoma cells, following incubation between 48 and 72 hours, is less than 20 $\mu \mathrm{g} / \mathrm{ml}$, while it is less than $4 \mu \mathrm{g} / \mathrm{ml}$ for pure compounds [20]. Table 2 shows that four ethanolic plant extracts exhibited high cytotoxicity against MCF7 cells. 


\begin{tabular}{|c|c|c|c|c|}
\hline Number & Plant Family & Plant Name & $\begin{array}{l}\text { Part } \\
\text { Used }\end{array}$ & $\begin{array}{l}\% \quad \text { survival } \pm \\
\text { standard deviation }\end{array}$ \\
\hline 1 & Araceae & $\begin{array}{l}\text { Arum } \\
\text { palaestinum }\end{array}$ & $\mathrm{L}$ & $99.81 \pm 4.25$ \\
\hline 2 & Arecaceae & $\begin{array}{l}\text { Phoenix } \\
\text { dactylifera }\end{array}$ & $\mathrm{L}$ & $88.55 \pm 9.11$ \\
\hline 3 & Boraginaceae & $\begin{array}{l}\text { Alkanna } \\
\text { strigosa }\end{array}$ & $\mathrm{H}$ & $99.93 \pm 6.81$ \\
\hline 4 & Boraginaceae & $\begin{array}{l}\text { Asperugo } \\
\text { procumbens }\end{array}$ & $\mathrm{H}$ & $92.42 \pm 11.52$ \\
\hline 5 & Cactaceae & $\begin{array}{l}\text { Opuntia ficus- } \\
\text { indica }\end{array}$ & $L$ & $78.81 \pm 7.69$ \\
\hline 6 & Capparaceae & $\begin{array}{l}\text { Capparis } \\
\text { spinosa }\end{array}$ & $L$, St & $111.06 \pm 8.97$ \\
\hline 7 & Capparaceae & $\begin{array}{l}\text { Capparis } \\
\text { spinosa }\end{array}$ & $\mathrm{Fr}$ & $111.32 \pm 12.52$ \\
\hline 8 & Capparaceae & $\begin{array}{l}\text { Capparis } \\
\text { spinosa }\end{array}$ & $\mathrm{R}$ & $65.2 \pm 7.53$ \\
\hline 9 & Capparaceae & $\begin{array}{l}\text { Capparis } \\
\text { spinosa }\end{array}$ & $L$ & $111.44 \pm 11.07$ \\
\hline 10 & Capparaceae & $\begin{array}{l}\text { Capparis } \\
\text { spinosa }\end{array}$ & $\mathrm{F}$ & $117.22 \pm 5.67$ \\
\hline 11 & Caprifoliaceae & $\begin{array}{l}\text { Sambucus } \\
\text { nigra }\end{array}$ & $\mathrm{L}$ & $94.89 \pm 7.26$ \\
\hline 12 & Caprifoliaceae & $\begin{array}{l}\text { Sambucus } \\
\text { nigra }\end{array}$ & $F$ & $100.56 \pm 8.89$ \\
\hline 13 & Caryophyllaceae & $\begin{array}{l}\text { Ankyropetalum } \\
\text { gypsophloides }\end{array}$ & $\mathrm{R}$ & $90.93 \pm 9.33$ \\
\hline 14 & Caryophyllaceae & $\begin{array}{l}\text { Paronychia } \\
\text { argentea }\end{array}$ & $\mathrm{F}$ & $84.11 \pm 7.32$ \\
\hline 15 & Chenopodiaceae & Beta vulgaris & $\mathrm{H}$ & $103.1 \pm 3.62$ \\
\hline 16 & Cistaceae & Cistus creticus & $\mathrm{H}$ & $72.32 \pm 5.38$ \\
\hline 17 & Compositae & $\begin{array}{l}\text { Achillea } \\
\text { biberstenii }\end{array}$ & $L, F$ & $81.64 \pm 3.3$ \\
\hline 18 & Compositae & $\begin{array}{l}\text { Achillea } \\
\text { santolina }\end{array}$ & $L, F$ & $46.54 \pm 4.00$ \\
\hline 19 & Compositae & $\begin{array}{l}\text { Anthemis } \\
\text { palaestinum }\end{array}$ & $L, F$ & $91.71 \pm 4.78$ \\
\hline 20 & Compositae & $\begin{array}{l}\text { Centaurea } \\
\text { iberica }\end{array}$ & $L, F$ & $102.15 \pm 8.20$ \\
\hline 21 & Compositae & $\begin{array}{l}\text { Cichorium } \\
\text { intybus }\end{array}$ & $L, F$ & $105.15 \pm 5.74$ \\
\hline
\end{tabular}




\begin{tabular}{|c|c|c|c|c|}
\hline 22 & Compositae & $\begin{array}{l}\text { Conyza } \\
\text { bonariensis }\end{array}$ & $\mathrm{H}$ & $84.89 \pm 17.26$ \\
\hline 23 & Compositae & $\begin{array}{l}\text { Conyza } \\
\text { canadiensis }\end{array}$ & $\mathrm{H}$ & $40.28 \pm 3.39$ \\
\hline 24 & Compositae & $\begin{array}{l}\text { Inula } \\
\text { graveolens }\end{array}$ & $\mathrm{F}$ & $5.29 \pm 0.41$ \\
\hline 25 & Compositae & $\begin{array}{l}\text { Varthemia } \\
\text { iphionoides }\end{array}$ & $L, F$ & $84.95 \pm 8.91$ \\
\hline 26 & Convolvulaceae & $\begin{array}{l}\text { Convolvulus } \\
\text { betonisifolius }\end{array}$ & $\mathrm{H}$ & $95.44 \pm 7.38$ \\
\hline 27 & Cruciferae & Cardaria draba & $\mathrm{H}$ & $111.05 \pm 6.47$ \\
\hline 28 & Cruciferae & Eruca sativa & $\mathrm{R}$ & $98.75 \pm 6.46$ \\
\hline 29 & Cruciferae & $\begin{array}{l}\text { Lepidium } \\
\text { sativum** }\end{array}$ & $\mathrm{L}$ & $105.23 \pm 8.03$ \\
\hline 30 & Cucurbitaceae & $\begin{array}{l}\text { Momordica } \\
\text { balsamina }\end{array}$ & L, St & $100.44 \pm 9.83$ \\
\hline 31 & Elaeagnaceae & $\begin{array}{l}\text { Eleagnus } \\
\text { angustifolia }\end{array}$ & $\mathrm{L}$ & $77.8 \pm 7.29$ \\
\hline 32 & Ericaceae & $\begin{array}{l}\text { Arbutus } \\
\text { andrachne }\end{array}$ & $\mathrm{L}$ & $103.48 \pm 10.30$ \\
\hline 33 & Ericaceae & $\begin{array}{l}\text { Arbutus } \\
\text { andrachne }\end{array}$ & St & $111.05 \pm 8.84$ \\
\hline 34 & Euphorbiaceae & $\begin{array}{l}\text { Euphorbia } \\
\text { hierosolyminata }\end{array}$ & $\mathrm{H}$ & $74.68 \pm 7.75$ \\
\hline 35 & Euphorbiaceae & $\begin{array}{l}\text { Euphorbia } \\
\text { peplus }\end{array}$ & $\mathrm{H}$ & $78.16 \pm 4.58$ \\
\hline 36 & Euphorbiaceae & $\begin{array}{l}\text { Mercurialis } \\
\text { annua* }\end{array}$ & $\mathrm{L}$ & $102.57 \pm 9.26$ \\
\hline 37 & Euphorbiaceae & $\begin{array}{l}\text { Mercurialis } \\
\text { annua }\end{array}$ & $\mathrm{L}$ & $100.88 \pm 8.23$ \\
\hline 38 & Hippocastanaceae & $\begin{array}{l}\text { Aesculus } \\
\text { hippocastani }\end{array}$ & L & $85.29 \pm 7.22$ \\
\hline 39 & Hypericaceae & $\begin{array}{l}\text { Hypericum } \\
\text { triquetrifolium }\end{array}$ & L, St & $97.12 \pm 9.24$ \\
\hline 40 & Iridaceae & Iris germanica & $F^{*}$ & $73.85 \pm 11.16$ \\
\hline 41 & Iridaceae & Iris nigricans & $F^{*}$ & $91.07 \pm 7.81$ \\
\hline 42 & Labiatae & Ajuga chia & $\mathrm{H}$ & $101.08 \pm 1.87$ \\
\hline 43 & Labiatae & $\begin{array}{l}\text { Ballota } \\
\text { undulata }\end{array}$ & L & $94.83 \pm 6.07$ \\
\hline 44 & Labiatae & $\begin{array}{l}\text { Marrubium } \\
\text { vulgare }\end{array}$ & $L, F$ & $72.68 \pm 6.12$ \\
\hline
\end{tabular}




\begin{tabular}{|c|c|c|c|c|}
\hline 45 & Labiatae & $\begin{array}{l}\text { Nepeta } \\
\text { curviflora }\end{array}$ & $L, F$ & $90.93 \pm 6.83$ \\
\hline 46 & Labiatae & Phlomis syriaca & $\mathrm{F}$ & $103.86 \pm 6.54$ \\
\hline 47 & Labiatae & Salvia dominica & $\mathrm{L}$ & $9.69 \pm 0.84$ \\
\hline 48 & Labiatae & $\begin{array}{l}\text { Salvia } \\
\text { hierosolymitana }\end{array}$ & L & $85.92 \pm 10.25$ \\
\hline 49 & Labiatae & Salvia indica & $\mathrm{L}$ & $100.56 \pm 6.70$ \\
\hline 50 & Labiatae & $\begin{array}{l}\text { Teucrium } \\
\text { leucocladum }\end{array}$ & $\mathrm{F}, \mathrm{L}$ & $60.25 \pm 10.33$ \\
\hline 51 & Labiatae & $\begin{array}{l}\text { Teucrium } \\
\text { polium }\end{array}$ & $\mathrm{F}, \mathrm{L}$ & $77.85 \pm 8.25$ \\
\hline 52 & Labiatae & $\begin{array}{l}\text { Thymus } \\
\text { capitatus }\end{array}$ & L,F & $86.61 \pm 5.95$ \\
\hline 53 & Leguminosae & $\begin{array}{l}\text { Alhagi } \\
\text { maurorum }\end{array}$ & $\mathrm{R}$ & $69.90 \pm 4.14$ \\
\hline 54 & Leguminosae & $\begin{array}{l}\text { Anagyris } \\
\text { foetida }\end{array}$ & $\mathrm{L}$ & $106.19 \pm 2.51$ \\
\hline 55 & Leguminosae & $\begin{array}{l}\text { Astragalus } \\
\text { oocephalus }\end{array}$ & L & $74.72 \pm 5.20$ \\
\hline 56 & Leguminosae & $\begin{array}{l}\text { Melilotus } \\
\text { indicus }\end{array}$ & L & $80.30 \pm 6.31$ \\
\hline 57 & Leguminosae & Ononis natrix & $L, F$ & $90.01 \pm 4.68$ \\
\hline 58 & Leguminosae & $\begin{array}{l}\text { Trifolium } \\
\text { purpureum }\end{array}$ & $\mathrm{F}, \mathrm{L}$ & $95.79 \pm 5.76$ \\
\hline 59 & Liliaceae & $\begin{array}{l}\text { Allium } \\
\text { neoplitanum }\end{array}$ & $\mathrm{H}$ & $99.86 \pm 5.15$ \\
\hline 60 & Ranunculaceae & $\begin{array}{l}\text { Clematus } \\
\text { cirrhosa }\end{array}$ & $\mathrm{H}$ & $77.82 \pm 9.37$ \\
\hline 61 & Resedaceae & Reseda lutea & $\mathrm{Fr}, \mathrm{L}, \mathrm{F}$ & $104.69 \pm 8.68$ \\
\hline 62 & Rhamnaceae & Zizyphus jujuba & L & $96.42 \pm 9.27$ \\
\hline 63 & Rubiaceae & $\begin{array}{l}\text { Gallium } \\
\text { arabicum }\end{array}$ & $\mathrm{H}$ & $100.47 \pm 2.67$ \\
\hline 64 & Rubiaceae & Rubia tinctoria & $\mathrm{L}$ & $101.03 \pm 6.84$ \\
\hline 65 & Rutaceae & $\begin{array}{l}\text { Ruta } \\
\text { chalepensis }\end{array}$ & $\mathrm{F}, \mathrm{L}$ & $80.33 \pm 4.76$ \\
\hline 66 & Santalaceae & Ossyris album & L,S & $87 \pm 17.23$ \\
\hline 67 & Simarubiaceae & $\begin{array}{l}\text { Ailanthus } \\
\text { altissima }\end{array}$ & $\mathrm{F}$ & $106.22 \pm 11.37$ \\
\hline
\end{tabular}




\begin{tabular}{|c|c|c|c|c|}
\hline 68 & Simarubiaceae & $\begin{array}{l}\text { Ailanthus } \\
\text { altissima }\end{array}$ & $\mathrm{L}$ & $109.4 \pm 9.87$ \\
\hline 69 & Simarubiaceae & $\begin{array}{l}\text { Ailanthus } \\
\text { altissima }\end{array}$ & $\mathrm{Fr}$ & $94.57 \pm 5.59$ \\
\hline 70 & Tiliaceae & Tilia cordata & $\mathrm{L}$ & $91.42 \pm 9.44$ \\
\hline 71 & Umbelliferae & Ammi majus & $\mathrm{F}, \mathrm{S}$ & $87.4 \pm 8.97$ \\
\hline 72 & Umbelliferae & $\begin{array}{l}\text { Apium } \\
\text { graveolens* }\end{array}$ & $\mathrm{L}$ & $101.76 \pm 8.88$ \\
\hline 73 & Urticaceae & $\begin{array}{l}\text { Pariteria } \\
\text { alsinifolia }\end{array}$ & $\mathrm{L}$ & $66.87 \pm 8.31$ \\
\hline 74 & Urticaceae & Urtica dioica & L, St & $93.12 \pm 8.88$ \\
\hline 75 & Urticaceae & Urtica urens & $\mathrm{L}$ & $103.94 \pm 5.2$ \\
\hline 76 & Zygophyllaceae & $\begin{array}{l}\text { Peganum } \\
\text { harmala }\end{array}$ & $L$ & $97.94 \pm 9.00$ \\
\hline
\end{tabular}

Tab. 1. Percentage cell survival of MCF7 cells following 72 hours exposure to 50 $\mu \mathrm{g} / \mathrm{ml}$ fractions from ethanolic plant extracts.

L: leaves, S: seeds, St: stems, F: flowers, Fr: fruits, R: Roots, H: herb, *: fresh plant used.

The data presented in Table 1 show that the ethanolic extracts of five plants that belong to the families of Compositae and Labiatae exhibited high cytotoxic activity. Calculation of the $\mathrm{IC}_{50}$ values for these extracts confirmed that the most potent plant extract was I. graveolens $\left(\mathrm{IC}_{50} 3.83 \mu \mathrm{g} / \mathrm{ml}\right)$ followed by $S$. dominica $\left(\mathrm{IC}_{50} 7.28 \mu \mathrm{g} / \mathrm{ml}\right)$, C. canadiensis $\left(\mathrm{IC}_{50} 12.76 \mu \mathrm{g} / \mathrm{ml}\right)$ and $A$. santolina $\left(\mathrm{IC}_{50} 24.12 \mu \mathrm{g} / \mathrm{ml}\right)$. Among these five plant species the least active was $T$. leucocladum $\left(\mathrm{IC}_{50} 39.242 \mu \mathrm{g} / \mathrm{ml}\right)$.

\begin{tabular}{|l|l|}
\hline Plant extract & $\mathbf{I C}_{50} \pm$ Standard deviation \\
\hline Achillea santolina & $24.12 \pm 1.927$ \\
\hline Salvia dominica & $7.28 \pm 1.150$ \\
\hline Inula graveolens & $3.833 \pm .177$ \\
\hline Teucrium leucocladum & $39.242 \pm 8.727$ \\
\hline Conyza canadiensis & $12.76 \pm 2.475$ \\
\hline
\end{tabular}

Tab. 2. In vitro cytotoxic activity (IC $50 \mu \mathrm{g} / \mathrm{ml} \pm$ Standard deviation) of crude extracts tested against MCF7 cell line for exposure of 72 hours. 




Fig. 1. Growth inhibition of MCF7 cell line by active plant extracts. Results present the average and standard deviation of 6 replicates.

The cytotoxic activity was further studied using chloroform and water extracts of the potent plants and for these, the activity was mainly in the chloroform and/or ethanolic extracts (Table 3).

\begin{tabular}{|l|l|l|l|}
\hline Plant extract & Chloroform extract & Water extract & Ethanolic extract \\
\hline Achillea santolina & $15.49 \pm 1.45$ & $96.79 \pm 3.04$ & $46.54 \pm 4.0$ \\
\hline Salvia dominica & $47.43 \pm 4.57$ & $100.96 \pm 8.30$ & $9.69 \pm 0.84$ \\
\hline Inula graveolens & $6.80 \pm 1.73$ & $74.23 \pm 8.93$ & $5.288 \pm 0.41$ \\
\hline $\begin{array}{l}\text { Conyza } \\
\text { canadiensis }\end{array}$ & $36.32 \pm 9.35$ & $105.13 \pm 5.56$ & $40.281 \pm 3.40$ \\
\hline
\end{tabular}

Tab. 3. Survival rate of MCF7 cells treated with different extracts at the concentration of $50 \mu \mathrm{g} / \mathrm{ml}$ at exposure time of $72 \mathrm{~h} \pm$ S.E.M. 
The results of the phytochemical screening of the plant species with potent anticancer activity are given in Table 4 . Flavonoids, terpenoids and phenolics were identified in all tested plants while the presence of alkaloids could be weakly detected only in one species (A. santolina).

\begin{tabular}{|l|l|l|l|l|l|}
\hline Plant name & alkaloids & flavonoids & terpenoids & phenolic & coumarins \\
\hline Achillea santolina & $-1+$ & ++ & ++ & ++ & + \\
\hline Salvia dominica & - & + & + & + & + \\
\hline Inula graveolens & - & ++ & + & ++ & + \\
\hline Conyza canadiensis & - & ++ & ++ & + & - \\
\hline Teucrium leucocladum & - & ++ & ++ & ++ & - \\
\hline
\end{tabular}

Tab. 4. Phytochemical screening of plant extracts with high cytotoxic activity

Cytotoxicity screening models provide important preliminary data to help selecting plant extracts with potential antineoplastic properties for future work [21]. Sulforhodamine B assay is a well-established in vitro method for cytotoxicity against cancer cell lines and non-cancer cell lines, and here it was utilized to determine the selective activity of the extracts [15].

Several plant species rich in flavonoids are reported having disease preventive and therapeutic properties. This observation is of particular importance since flavonoids are ingredients of many vegetables and fruits and the association of vegetable and fruit consumption with reduced cancer risk has been reported [22, 23]. Antiproliferative activity recorded in the present study is in accordance with this finding, since the phytochemical evaluation indicated the presence of flavonoids in all of the four plant species with promising activity. Among these active plant species the genus 
Salvia has been investigated for cytotoxic activities on cultures of different human tumor cell lines using crude extracts, oily fractions or isolated compounds [24-26]. In a recent study Fiore et al. demonstrated antiproliferative activity for $S$. dominica, collected from Jordan, against colorectal adenocarcinoma, choriocarcinoma, prostate adenocarcinoma, B lymphoblast, glioblastoma and endometrium adenocarcinoma cell lines [27]. For the remaining plants with cytotoxic activities only scarce reports are available [28].

The ethanolic and chloroform extracts of I graveolens and C. canadiensis showed little difference in their potency, while the chloroform extract of $A$. santolina was found to be more active than the ethanolic extract indicating for non polar active principles responsible for the antiproliferative activity. In $S$. dominica, the ethanolic extract was found to be nearly five times more active than the chloroform extract.

In a parallel study, the 67 plants are under investigation for the antiproliferative activity against other cancer cell lines, namely A549 and HL60. In both cell lines and for the concentration $50 \mu \mathrm{g} / \mathrm{ml}$, the extracts were not toxic and the proliferation rate of the cells was not significantly different from that of the controls (untreated cells). The toxicity of these extracts on normal tissue culture and the exact determination of $\mathrm{IC}_{50}$ value is another point to be further assessed in order to clarify their safety.

Further studies are also in process to evaluate the most potent fraction of the four active plants and to isolate the constituents of these fractions.

\section{Acknowledgment}

The Deanship of Scientific Research in the University of Jordan is thanked for financial support. Mr. Rakan Tamim-Dari and Miss Faten Al-Haj are thanked for their technical assistance. 


\section{References}

[1] Dikshit A, Shahi SK, Pandey KP, Patra M, Shukla AC Aromatic plants a source of natural chemotherapeutants Nat. Acad. Sci. Letters,2004; 27(5\&6): 145-164.

[2] Newman DJ, Cragg GM, Snader KM. The influence of natural products upon drug discovery Nat Prod Rep, 2000; 17(3): 215-234.

[3] Newman DJ, Cragg GM, Snader KM, Natural products as sources of new drugs over the period 1981-2002 J Nat Prod., 2003; 66(7): 1022-1037.

[4] Kucuk O. New opportunities in chemoprevention research Cancer Invest., 2002; 20: 237-245

[5] Balunas MJ, Kinghorn AD, Drug discovery from medicinal plants Life Sci, 2005; 78: 431-441.

[6] Richardson M.A. Biopharmacologic and herbal therapies for cancer: research update from NCCAM J. Nutr., 2001; 131(11): 3037S-3040S

[7] Greenwald P. Cancer chemoprevention Br Med J , 2002; 324 (7339): 714-718.

[8] Ho JW, Leung YK, Chan CP Herbal medicine in the treatment of cancer Curr Med Chem Anticancer Agents,2002; 292: 209-214.

[9] Kim J, Park EJ, Cytotoxic anticancer candidates from natural resources Curr Med Chem Anticancer Agents, 2002; 2: 485-537.

[10] Mehta RG, Pezzuto JM, Discovery of cancer preventive agents from natural products: From plants to prevention.

Curr Oncol Rep, 2002; 4: 478-486.

[11] Kinghorn AD, Farnsworth NR, Soejarto DD, Cordell GA, Swanson SM, Pezzuto JM, Wani MC, Wall ME, Oberlies NH, Kroll DJ, Kramer RA, Rose WC, Vite GD, Fairchild CRM, Peterson RW, Wild R Natural inhibitors of carcinogenesis Pharmaceutical Biology, 2003; 41: 53-67. 
[12] Lampronti I, Martello D, Bianchi N, Borgatti M, Lambertini E, Piva R, Jabbar S, Choudhuri MSK, Khan MTH, Gambari R

In vitro antiproliferative effects on human tumor cell lines of extracts from the Bangladeshi medicinal plant Aegle marmelos Correa

Phytomedicine 2003; 10: 300-308.

[13] Cozzi P, Mongelli N, Suarto A

Recent anticancer cytotoxic agents

Curr Med Chem Anticancer Agents, 2004; 4: 93-121.

[14] Diwanay S, Chitre D, Patwardhan B,

Immunoprotection by botanical drugs in cancer chemotherapy

J Ethnopharmacol, 2004; 90: 49-55.

[15] Itharat A, Houghton PJ, Eno-Amooquaye E, Burke PJ, Sampson JH, Raman A In vitro cytotoxic activity of Thai medicinal plants used traditionally to treat cancer J Ethnopharmacol, 2004; 90: 33-38

[16] Ravelo ÁG, Estévez-Braun A, Chávez-Orellana H, Pérez-Sacau E, Mesa-Siverio $\mathrm{D}$

Recent studies on natural products as anticancer agents

Curr Top Med Chem, 2004; 4: 241-265.

[17] Lee CC, Houghton P,

Cytotoxicity of plants from Malaysia and Thailand used traditionally to treat cancer.

J Ethnopharmacol, 2005; 100: 237-243.

[18] Sehgal A

Anticancer drug discovery using chemical genomics

Current Med Chemistry, 2003; 10(9): 749-755.

[19] Wagner H, Bladt S

Plant drug analysis, a thin layer chromatography atlas. Berlin, Springer-Verlag, pp. 155, 176, 178 (1996).

[20] Boik J.

Natural Compounds in Cancer Therapy. Oregon Medical Press, Minnesota, USA, p. 25 (2001).

[21] Cardellina II JH, Fuller RW, Gamble WR, Westergaard C, Boswell J, Munro MHG, Currens M, Boyd M.

Evolving strategies for the selection dereplication and prioritization of antitumor and HIV-inhibitory natural products extracts. In: Bohlin, L., Bruhn, J.G. (Eds.), Bioassaay Methods in Natural Product Research and Development. Kluwer Academic Publishers, Dordrecht, pp. 25-36 (1999)

[22] Ferguson PJ, Kurowska E, Freeman DJ, Chambers AF, Koropatnick DJ.

A flavonoid fraction from cranberry extract inhibits proliferation of human tumor cell lines

J. Nutr., 2004; 134(6):1529-1535 
[23] Kanadaswami C, Lee L, Lee PH, Hwang J, Ke F, Huang Y, Lee M.

The antitumor activities of flavonoids

In Vivo, 2005; 19(5): 895-909.

[24] Foray L, Bertrand C, Pinguet F, Soulier M, Astre C, Marion C, Pelissier Y, Bessiere JM.

In vitro cytotoxic activity of three essential oils from Salvia species

Journal of Essential Oil Research, 1999; 11(4): 522-526.

[25] Esquivel B, Sanchez AA, Vergara F, Matus W, Hernandez-Ortega S, RamirezApan, M.T.

Abietane diterpenoids from the roots of some Mexican Salvia species (Labiatae):

Chemical diversity, phytogeographical significance and cytotoxic activity

Chem. Biodivers., 2005; 2(6): 738-747.

[26] Wang X, Xu J.

Salvianic acid A protects human neuroblastoma SH-SY5Y cells against MPP ${ }^{+}$ induced cytotoxicity

Neurosci. Res. 2005; 51(2): 129-138.

[27] Fiore G, Nencini C, Cavallo F, Capasso A, Bader A, Giorgi G, Micheli L.

In vitro antiproliferative effect of six Salvia species on human tumor cell lines.

Phytother Res, 2006; 20: 701-703.

[28] Topcu G, Oksuz S, Shieh HL, Cordell GA., Pezzuto JM, Bozok-Johansson C. Cytotoxic and antibacterial sesquiterpenes from Inula graveolens Phytochemistry, 1993; 33(2): 407-410. 